\title{
Sunflower diseases control by biological fungicides
}

\author{
Nadezhda Bushneva*, and Alexander Bushnev \\ V.S. Pustovoit All-Russian Research Institute of Oil Crops, 17 Filatova street, 350038 Krasnodar, \\ Russia
}

\begin{abstract}
The demand for organic food has grown rapidly over the last 25 years in many countries of the world. Organic farming standards require the application of biological products of disease control. The article presents the material on studying the effectiveness of fungicides based on microbiological antagonists against sunflower diseases. We carried out the study in 2020-2021 at V.S. Pustovoit All-Russian Research Institute of Oil Crops (VNIIMK) (Krasnodar). We established that the fungicides Geostim Fit type E, WS based on microbiological antagonists did not reduce the germination of sunflower seeds and actively suppressed seed infection. Their effectiveness against Alternaria spp. reached 50-74 \%, against Rhizopus spp. - 74-100\%, against bacteria - 76-80\%. Double treatment of sunflower plants with BFTIM, WS (different strains) reduced the frequency of bacterial blight to $37 \%$, of dry rot - to $60 \%$, of Alternaria blight - to $39 \%$, of Phoma rot - to $41 \%$, and of Fusarium blight - to 75 $\%$. The application scheme of Geostim Fit E (G), WS; BFTIM (E), WS; BFTIM (Zh), WS showed the best economic effectiveness with a seed yield of $3.56 \mathrm{t} / \mathrm{ha}$, net income of 122910 rubles, and profitability of $311 \%$.
\end{abstract}

\section{Introduction}

The demand for organic food has grown rapidly over the last 25 years in Europe, North America, and Asia. This is due to the fact that organic agriculture is good for the environment, soil, biodiversity, food quality, and food safety compared to traditional agriculture. Organic agriculture is also recognized as one of the alternative farming systems for overcoming climate change problems [1-4].

Organic farming standards, as defined by government laws and regulations in most countries, prohibit or limit the use of many external factors that are commonly used in traditional agriculture [5]. In particular, the standards of organic crop production prohibit the use of synthetic plant protection chemicals (fungicides, herbicides, insecticides, plant growth regulators) and basic mineral fertilizers (all sources of $\mathrm{N}, \mathrm{KCl}$, and superphosphate), which are commonly used in traditional farming systems [6-8]. Instead, standards require the regular application of organic fertilizers (e.g., manure and compost), the use of legumes in crop rotation (to increase nitrogen levels and balance nitrogen to phosphorus ratios in the soil), and the use of preventive and non-chemical plant protection methods, such as the use

\footnotetext{
* Corresponding author: naducha74@mail.ru
} 
of diverse crop rotations, resistant (tolerant) varieties, mechanical weeding as well as biological products for control of diseases and pests [5].

The harmfulness decrease of disease pathogens by fungal and bacterial antagonists is becoming increasingly common in crop protection [9-11]. For instance, antagonistic bacteria can secrete chitinase and protease enzymes, which are responsible for their effectiveness against many fungal pathogens [12]. Mixtures of microorganisms and their metabolites in the form of wettable powders and liquids help to reduce disease affection, increase seed germination and productivity indicators, obtain a preserved yield and additional income [13]. Polyfunctional preparations have a wide range of antifungal action, they include fungicides based on micromycetes of the Trichoderma spp. genus, which are effective in the control of fungal diseases of plants. In addition, it is established that Trichoderma spp. fungi increase plant growth, disease resistance, and abiotic stress [14].

Sunflower is a widespread oil crop, including the Krasnodar region, where the natural and climatic conditions are favorable for their cultivation. However, high sunflower yields are hindered by several diseases, which disrupt normal growth and development, and sometimes kill the plants. Annual phytosanitary inspections of the sunflower sowings in the Krasnodar region show that infestations by dry (Rhizopus) rot and bacterial blight are increasing. The aim of producers to reduce the number of pesticides used in crops cultivation, including sunflower, is stimulating the search for effective preparations against diseases based on microbiological antagonists.

Thereby, the purpose of this research was to evaluate the effectiveness of organic fungicides in the protection system of sunflower sowings against diseases in the conditions of the Krasnodar region.

\section{Materials and methods}

The article is based on the results of field trials of biological fungicides of the company OOO "Biotechagro" (Timashevsk, Russia) on the basis of microbiological antagonists against diseases of confectionery sunflower varieties of VNIIMK breeding (variety SPK), conducted in 2020-2021 on the leached chernozem of the Western Ciscaucasia in the central agroclimatic zone of the Krasnodar region at V.S. Pustovoit All-Russian Research Institute of Oil Crops (VNIIMK) (Krasnodar).

Sunflower is affected by diseases throughout the growing season, so we included a seed treatment and two plant treatments in the research scheme to control the diseases more effectively. We tested 4 variants of sunflower crop protection schemes against diseases. Each scheme included: treatment of sunflower seeds with fungicides under the trademark Geostim Fit type E based on Trichoderma viride, Pseudomonas koreensis, Bacillus subtilis (different strains of antagonists), and treatment of plants at the stage of 2-3 pairs of leaves and at the budding stage with biofungicides under the BFTIM trademark based on Bacillus amyloliquefaciens (titer $1 \times 10^{9} \mathrm{CFU} / \mathrm{ml}$ ) (different strains of antagonists). The variant with untreated sunflower seeds and plants was the control. The standard was the variant with the recommended chemical fungicides (for seed treatment - Fludioxonil, SC (25 g/l) + Mefenoxam, AQ $(350 \mathrm{~g} / \mathrm{l})-5.0+3.0 \mathrm{l} / \mathrm{t}$; for the first plant treatment - Azoxystrobin + Cyproconazole, SC $(200 \mathrm{~g} / \mathrm{l}+80 \mathrm{~g} / \mathrm{l})-0.8 \mathrm{l} / \mathrm{ha}$; for the second plant treatment Dimoxystrobin + Boscalid, SC (200 g/1 + $200 \mathrm{~g} / \mathrm{l})-0.5 \mathrm{l} / \mathrm{ha})$ (Table 1). 
Table 1. Scheme of field trials of sunflower crop protection systems against diseases in the Krasnodar region, 2020-2021.

\begin{tabular}{|c|c|c|c|}
\hline № & Variant & $\begin{array}{l}\text { Application rate, } 1 / \mathrm{t}, \\
1 / \text { ha }\end{array}$ & Method of application \\
\hline 1 & Control & - & without treatment \\
\hline \multirow[t]{3}{*}{2} & $\begin{array}{l}\text { Fludioxonil, SC + Mefenoxam, } \\
\text { AQ }\end{array}$ & $5.0+3.0$ & seed treatment \\
\hline & $\begin{array}{l}\text { Azoxystrobin + Cyproconazole, } \\
\text { SC }\end{array}$ & 0.8 & $\begin{array}{l}\text { treatment at the stage of 2-3 pairs } \\
\text { leaves }\end{array}$ \\
\hline & Dimoxystrobin + Boscalid, SC & 0.5 & treatment at the budding stage \\
\hline \multirow[t]{3}{*}{3} & Geostim Fit E (A), WS & 2.0 & seed treatment \\
\hline & BFTIM (A), WS & 2.0 & $\begin{array}{l}\text { treatment at the stage of } 2-3 \text { pairs } \\
\text { leaves }\end{array}$ \\
\hline & BFTIM (B), WS & 3.0 & treatment at the budding stage \\
\hline \multirow[t]{3}{*}{4} & Geostim Fit E (B), WS & 3.0 & seed treatment \\
\hline & BFTIM (V), WS & 2.0 & $\begin{array}{l}\text { treatment at the stage of } 2-3 \text { pairs } \\
\text { leaves }\end{array}$ \\
\hline & $\operatorname{BFTIM}(\mathrm{G}), \mathrm{WS}$ & 3.0 & treatment at the budding stage \\
\hline \multirow[t]{3}{*}{5} & Geostim Fit E (V), WS & 3.0 & seed treatment \\
\hline & BFTIM (D), WS & 3.0 & $\begin{array}{l}\text { treatment at the stage of } 2-3 \text { pairs } \\
\text { leaves }\end{array}$ \\
\hline & BFTIM (D), WS & 3.0 & treatment at the budding stage \\
\hline \multirow[t]{3}{*}{6} & Geostim Fit E (G), WS & 5.0 & seed treatment \\
\hline & BFTIM (E), WS & 2.0 & $\begin{array}{l}\text { treatment at the stage of 2-3 pairs } \\
\text { leaves }\end{array}$ \\
\hline & BFTIM (Zh), WS & 3.0 & treatment at the budding stage \\
\hline
\end{tabular}

We carried out the presowing treatment of sunflower seeds with fungicides on a laboratory encrustator Hege. We sowed the seeds using a GASPARDO-MT 8 seeder according to the scheme with a seeding rate recommended for this variety: $400.000 \mathrm{pcs} / \mathrm{ha}$, the number of experiment replications was 3, the area of one plot was $112 \mathrm{~m}^{2}$. We recorded all manifestations of diseases and made calculation of the biological effectiveness of fungicides according to the guidelines for registration testing of fungicides in agriculture [15]. Sunflower was harvested using an Acros-530 combine, the yield was corrected to 100 $\%$ of purity and $10 \%$ of moisture content. We processed the research data by analysis of variance using the SPSS software.

\section{Results and discussion}

We determined the sowing qualities of sunflower seeds and their infection with pathogens before sowing. We found that the laboratory germination of seeds untreated with fungicides was lower and at the level of $87 \%$ due to the presence of a seed infection complex, consisting of the fungi Alternaria spp., Rhizopus spp., and bacteria (Xanthomonas spp., Pseudomonas spp.) with 34,15 , and $10 \%$ of affected seeds and seedlings, respectively. The seed treatment with fungicides increased germination by reducing pathogen infection. In variants with the treatment of seeds with Geostim Fit E, WS (different strains), germination exceeded the control and reached 90-92\%, germination was highest with seed treatment with Fludioxonil, SC + Mefenoxam, AQ - $96 \%$. Compared with the control, the variants showed the decrease of the infection of seeds and seedlings: with the fungi of Alternaria spp. - by $50-88 \%$, with Rhizopus spp. - by $44-100 \%$. The chemical standard and the variant with seeds treatment with Geostim Fit E (A), WS showed the best results against fungal infection. We noted the decrease of seed infection with bacterial blight by $76-80 \%$ 
when seeds were treated with biological fungicides; chemical preparations had the lowest effectiveness $-30 \%$.

During the period from seedling emergence to sunflower maturity, we recorded the occurrence of the diseases: the crop plants were infected with bacterial blights (Xanthomonas spp., Pseudomonas spp.), dry rot (Rhizopus spp.), Alternaria blight (Alternaria spp.), Fusarium blight (Fusarium spp.), and Phoma rot (Plenodomus lindquistii (Frezzi)).

The prevalence of dry rot in the experiment was 33.3-32.9 \%. It was lower in variants № 6 Geostim Fit E (G), WS; BFTIM (E), WS; BFTIM (Zh), WS) and № 4 (Geostim Fit E (B), WS; BFTIM (V), WS; BFTIM (G), WS) - 13.0 and 15.7 $\%$, respectively (Table 2 ).

Table 2. Effect of fungicides on disease prevalence (\%) in sunflower sowing, V.S. Pustovoit AllRussian Research Institute of Oil Crops, 2020-2021.

\begin{tabular}{|c|c|c|c|c|c|c|}
\hline № & Variant & 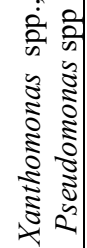 & 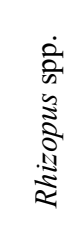 & 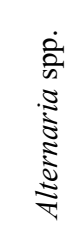 & 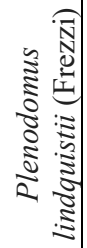 & 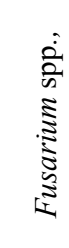 \\
\hline 1 & Control (without treatment) & 54.0 & 32.9 & 24.0 & 17.0 & 20.0 \\
\hline 2 & $\begin{array}{l}\text { Fludioxonil, SC + Mefenoxam, AQ; } \\
\text { Azoxystrobin + Cyproconazole, SC; } \\
\text { Dimoxystrobin + Boscalid, SC }\end{array}$ & 42.0 & 20.6 & 14.0 & 9.1 & 5.0 \\
\hline 3 & $\begin{array}{l}\text { Geostim Fit E (A), WS; BFTIM (A), WS; } \\
\text { BFTIM (B), WS }\end{array}$ & 37.2 & 24.0 & 16.0 & 12.0 & 9.0 \\
\hline 4 & $\begin{array}{l}\text { Geostim Fit E (B), WS; BFTIM (V), WS; } \\
\text { BFTIM (G), WS }\end{array}$ & 32.0 & 15.7 & 18.2 & 10.0 & 7.2 \\
\hline 5 & $\begin{array}{l}\text { Geostim Fit E (V), WS; BFTIM (D), WS; } \\
\text { BFTIM (D), WS }\end{array}$ & 34.7 & 19.0 & 20.0 & 13.6 & 9.0 \\
\hline 6 & $\begin{array}{l}\text { Geostim Fit E (G), WS; BFTIM (E), WS; } \\
\text { BFTIM (Zh), WS }\end{array}$ & 34.0 & 13.0 & 14.6 & 13.0 & 5.0 \\
\hline
\end{tabular}

We observed the maximum number of sunflower plants infected with bacterial blight in the control and the standard -54.0 and $42.0 \%$, respectively. The bacterial blight in other variants was at the level of 32.0-37.2 \%. The prevalence of Fusarium blight in the control reached $20.0 \%$, while in the variants with fungicides it was significantly lower, averaging $5.0-9.0 \%$. Sunflower infection with Alternaria blight in the control was $24.0 \%$, while in the variants with treatment it was slightly lower $-14.0-20.0 \%$. By the end of the sunflower growing season, the highest Phoma rot prevalence was in the control $(17.0 \%)$. The sunflower treatment with fungicides kept the disease occurrence at the level of 9.1-13.6\%.

Based on the results of records of the prevalence of the diseases, we calculated the biological effectiveness of fungicides. The application of chemical preparations reduced the bacterial blight prevalence by only $20 \%$, while the biological fungicides showed effectiveness at the level of 31-40 \%. The variant № 6 (Geostim Fit E (G), WS; BFTIM (E), WS; BFTIM (Zh), WS) was the most effective against dry rot $-60 \%$. The variant № 3 
(Geostim Fit E (A), WS; BFTIM (A), WS; BFTIM (B), WS) had the minimum biological effectiveness $-27 \%$ (Table 3 ).

Table 3. Biological effectiveness (\%) of fungicides against diseases on sunflower, V.S. Pustovoit All-Russian Research Institute of Oil Crops, 2020-2021.

\begin{tabular}{|c|c|c|c|c|c|c|}
\hline № & Variant & 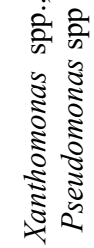 & 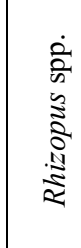 & 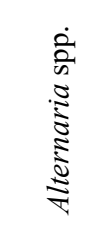 & 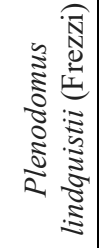 & 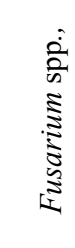 \\
\hline 1 & Control (without treatment) & $54.0 *$ & $32.9^{*}$ & $24.0^{*}$ & $17.0 *$ & $20.0^{*}$ \\
\hline 2 & $\begin{array}{l}\text { Fludioxonil, SC + Mefenoxam, AQ; } \\
\text { Azoxystrobin + Cyproconazole, SC; } \\
\text { Dimoxystrobin + Boscalid, SC }\end{array}$ & 22 & 37 & 41 & 46 & 75 \\
\hline 3 & $\begin{array}{l}\text { Geostim Fit E (A), WS; BFTIM (A), WS; } \\
\text { BFTIM (B), WS }\end{array}$ & 31 & 27 & 33 & 29 & 55 \\
\hline 4 & $\begin{array}{l}\text { Geostim Fit E (B), WS; BFTIM (V), WS; } \\
\text { BFTIM (G), WS }\end{array}$ & 35 & 32 & 24 & 41 & 64 \\
\hline 5 & $\begin{array}{l}\text { Geostim Fit E (V), WS; BFTIM (D), WS; } \\
\text { BFTIM (D), WS }\end{array}$ & 35 & 42 & 16 & 20 & 55 \\
\hline 6 & $\begin{array}{l}\text { Geostim Fit E (G), WS; BFTIM (E), WS; } \\
\text { BFTIM (Zh), WS }\end{array}$ & 37 & 60 & 39 & 23 & 75 \\
\hline
\end{tabular}

* - the diseases prevalence in the control, $\%$

The effectiveness of fungicides against Alternaria blight was $16-41 \%$, the best variants being № 2 (Fludioxonil, SC + Mefenoxam, AQ; Azoxystrobin + Cyproconazole, SC; Dimoxystrobin + Boscalid, SC) and № 6 (Geostim Fit E (G), WS; BFTIM (E), WS; BFTIM (Zh), WS) -41 and $39 \%$, respectively. The standard and the variant № 6 (Geostim Fit E (G), WS; BFTIM (E), WS; BFTIM (Zh), WS) had the maximum decrease of Fusarium blight prevalence $-75 \%$; in the remaining variants, the decrease was within 55-64\%. The variants № 2 (Fludioxonil, SC + Mefenoxam, AQ; Azoxystrobin + Cyproconazole, SC; Dimoxystrobin + Boscalid, SC) and № 4 (Geostim Fit E (B), WS; BFTIM (V), WS; BFTIM (G), WS) were the best against Phoma rot with biological effectiveness of 46 and $41 \%$, respectively.

We determined the economic effectiveness of the studied protection schemes after sunflower maturing. Sunflower seed yield in the variants Geostim Fir E (A), WS; BFTIM (A), WS; BFTIM (B), WS, and Geostim Fit E (B), WS; BFTIM (V), WS; BFTIM (G), WS was lower compared to the control by 0.20 and $0.33 \mathrm{t} / \mathrm{ha}$, respectively, but we observed no significant differences between them. The variant № 6 (Geostim Fit E (G), WS; BFTIM (E), WS; BFTIM (Zh), WS) gave the highest sunflower yield, with a preserved yield of $0.50 \mathrm{t} / \mathrm{ha}$. We calculated the economic effectiveness based on the results of trials of plant protection schemes against diseases on sunflower (Table 4). 
Table 4. Economic effectiveness of plant protection systems against diseases on sunflower, V.S. Pustovoit All-Russian Research Institute of Oil Crops 2020-2021.

\begin{tabular}{|c|c|c|c|c|c|}
\hline № & Variant & 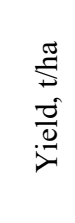 & 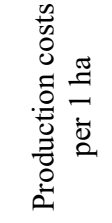 & 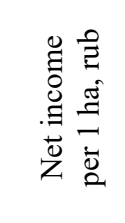 & 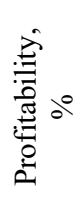 \\
\hline 1 & Control (without treatment) & 3.06 & 38396 & 102364 & 267 \\
\hline 2 & $\begin{array}{l}\text { Fludioxonil, SC + Mefenoxam, AQ; } \\
\text { Azoxystrobin + Cyproconazole, SC; } \\
\text { Dimoxystrobin + Boscalid, SC }\end{array}$ & 3.32 & 47441 & 105279 & 222 \\
\hline 3 & $\begin{array}{l}\text { Geostim Fit E (A), WS; BFTIM (A), WS; } \\
\text { BFTIM (B), WS }\end{array}$ & 2.86 & 40034 & 91526 & 229 \\
\hline 4 & $\begin{array}{l}\text { Geostim Fit E (B), WS; BFTIM (V), WS; } \\
\text { BFTIM (G), WS }\end{array}$ & 2.73 & 39226 & 86354 & 220 \\
\hline 5 & $\begin{array}{l}\text { Geostim Fit E (V), WS; BFTIM (D), WS; } \\
\text { BFTIM (D), WS }\end{array}$ & 3.31 & 40457 & 111803 & 276 \\
\hline 6 & $\begin{array}{l}\text { Geostim Fit E (G), WS; BFTIM (E), WS; } \\
\text { BFTIM (Zh), WS }\end{array}$ & 3.56 & 39470 & 122910 & 311 \\
\hline
\end{tabular}

The results show that the cost of cultivating 1 ha of sunflower was in the range of 38396 - $47441 \mathrm{rubles} / \mathrm{ha}$, including the additional cost of preparations $-839.14-8915.0 \mathrm{rubles} / \mathrm{ha}$. Without fungicide treatments, costs were lowest and reached 38396 rubles/ha, while the standard had the highest costs - 47441 rubles/ha. The highest net income per 1 ha in the experiment was received in the application of Geostim Fit E (G), WS; BFTIM (E), WS; BFTIM (Zh), WS - 122910 rubles/ha, which exceeded the standard by 17631 rubles/ha. Profitability in this variant was $311 \%$.

\section{Conclusions}

The research showed that the fungicides Geostim Fit of type E, WS based on the microbiological antagonists did not reduce the germination of sunflower seeds and actively suppressed seed infection. Their effectiveness against Alternaria spp. reached 50-74 \%, against Rhizopus spp. - 74-100\%, against bacteria - 76-80\%. Double treatment of sunflower plants with BFTIM, WS (different strains) reduced the frequency of bacterial blight to $37 \%$, of dry rot - to $60 \%$, of Alternaria blight - to 39 $\%$, of Phoma rot - to $41 \%$, and of Fusarium blight - to $75 \%$. The application of the scheme of Geostim Fit E (G), WS; BFTIM (E), WS; BFTIM (Zh), WS in the cultivation technology of confectionery sunflower showed the best economic effectiveness with a seed yield of $3.56 \mathrm{t} / \mathrm{ha}$, net income of 122910 rubles, and profitability of $311 \%$.

\section{References}

1. H. Willer, L. Kilcher, the World of Organic Agriculture. Statistics and Emerging Trends 2011. FiBL-IFOAM Report IFOAM, Bonn and FiBL, Frick (2011)

2. Y. Joshi, Z. Rahman, International Strategic Management Review, 3(1-2), 128-143 (2015)

3. A. Naorem, J. Maverick, P. Singh, Sh. K. Udayana, Advances in Organic Farming Agronomic Soil Management Practices, 47-58 (2021) 
4. T. Gomiero, M.G. Paoletti, D. Pimentel Critical Reviews in Plant Sciences, 27, 239254 (2008)

5. P. Bilsborrow, J. Cooper, C. Tétard-Jones, D. Średnicka-Tober, M. Barański, M. Eyre, Ch. Schmidt, P. Shotton, N. Volakakis, I. ICakmak, L. Ozturk, C. Leifert, S. Wilcockson, European Journal of Agronomy, 51, 71-80 (2013)

6. B. P. Baker, C. M. Benbrook, E. Groth III K. Benbrook Food Additives \& Contaminants, 19, 427-446 (2002)

7. H. Willer, L. Kilcher, The World of Organic Agriculture. Statistics and Emerging Trends 2016 Bonn and FiBL, Frick (2016)

8. H. Willer, L. Kilcher, The World of Organic Agriculture. Statistics and Emerging Trends 2017 Bonn and FiBL, Frick (2017)

9. A. Majeed, M.K. Abbasi, S. Hameed, S. Yasmin, M.K. Hanif, T. Naqqash, A. Imran, Microbiological Research, 216, 56-69 (2018)

10. Sh. Moin, S.A. Ali, K.A. Hasan, A. Tariq, V. Sultana, J. Ara, S. Ehteshamul-Haque, Crop Protection, 130 (2020)

11. M. Kgatle, B. Fletty, M. Truter, T. Aveling, Crop Protection, 132, 105-146 (2020)

12. W.T. Chang, M.L. Chen, S.L. Wang Microbiology and Biotechnology, 26, 945-950 (2010)

13. N.A. Nafady, M. Hashem, E.A. Hassan, H. Ahmed, S.A. Alamri, Biological Control 138 (2019)

14. R.N. Silva, V.N. Monteiro, A.S. Steindorff, E.V. Gomes, E.F. Noronha, C.J. Ulhoa, Fungal Biology, 123, 565-583 (2019)

15. K.V. Novozhilova, A.I. Anisimov, Guidelines for registration testing of fungicides in agriculture (2009) 